\title{
Laidunnuksen vaikutus hereford-sonnien ruhon ja lihan laatuun
}

\author{
Arto Huuskonen $^{1)}$, Susanna Jansson ${ }^{2)}$, Markku Honkavaara ${ }^{3)}$, Leena Tuomisto ${ }^{4)}$ ja Risto Kauppinen ${ }^{5)}$ \\ ${ }^{1)}$ Maa-ja elintarviketalouden tutkimuskeskus, Kotieläintuotannon tutkimus, Halolantie 31 A, 71750 \\ Maaninka,arto.huuskonen@mtt.fi \\ ${ }^{2)}$ Haapajärven ammattiopisto, Erkkiläntie 1,85800 Haapajärvi, susanna.jansson@cop.fi \\ 3) Lihateollisuuden tutkimuskeskus, PL 56,13101 Hämeenlinna, markku.honkavaara@ltk.fi \\ 4) Maa-ja elintarviketalouden tutkimuskeskus, Kotieläintuotannon tutkimus, Kuopion yliopisto, Biotie- \\ teiden laitos, PL 1627,70211Kuopio, leena.tuomisto@mtt.fi \\ 5)Savonia-ammattikorkeakoulu, PL 72,74101, Iisalmi, risto.kauppinen@savonia-amk.fi
}

\section{Tiivistelmä}

Sonnien laiduntaminen on harvinaista, ja siitä on hyvin vähän tutkimustuloksia. Yli vuodenikäisten sonnien laiduntamisesta pelätään yleensä olevan enemmän haittaa kuin hyötyä, koska sonnien katsotaan olevan tehottomia laiduntajia ja hankalia käsitellä laitumella. Laiduntamisen on todettu useissa tutkimuksissa muuttavan nautojen lihaksensisäisen rasvan rasvahappokoostumusta lisäämällä muun muassa terveellisen konjugoidun linolihapon eli CLA:n pitoisuutta. Ulkomaiset tutkimukset on kuitenkin suureksi osaksi tehty härillä ja usein niissä on verrattu voimakasta väkirehuruokintaa laidunruokintaan. Tämän tutkimuksen tavoitteena oli selvittää, miten laidunkasvatus vaikuttaa yli vuodenikäisten hereford-sonnien kasvuun, ruhon laatuun sekä lihan rasvahappokoostumukseen pihattokasvatukseen verrattuna.

Kokeessa oli 29 hereford-rotuista sonnia, jotka olivat kokeen alkaessa keskimäärin 14 kuukauden ikäisiä. Laidunryhmässä oli 15 sonnia, jotka laidunsivat kolmessa viiden sonnin ryhmässä. Vertailuryhmä (14 sonnia) kasvatettiin eristämättömässä pihatossa ryhmäkarsinoissa. Pihattoryhmät koostuivat yhdestä neljän ja kahdesta viiden sonnin ryhmästä. Koe kesti 62 vuorokautta (1.6.-1.8.2005). Laitumet oli jaettu lohkoihin, joita oli jokaisella ryhmällä käytössä neljä kesäkuun alusta heinäkuun puoliväliin. Heinäkuun puolivälin jälkeen otettiin käyttöön kaksi lisälohkoa, joilta oli korjattu ensimmäinen säilörehusato. Laidun oli timoteinurmea, jota lannoitettiin ja puhdistusniitettiin tarpeen mukaan. Laidunlohkoja syötettiin 3-7 päivän ajan. Pihattosonnit saivat vapaasti hyvälaatuista nurmisäilörehua. Sekä laitumella että pihatossa annettiin päivässä väkirehua (ohra) $5 \mathrm{~kg} / \mathrm{sonni}$ ja kivennäistä 150 g/sonni.

Kasvatustavalla ei ollut tilastollisesti merkitsevää vaikutusta kasvutuloksiin, mutta laidunnusjakson aikana päiväkasvut näyttivät kuitenkin olevan hieman heikompia laitumella kuin pihatossa. Kasvatustapa ei vaikuttanut sonnien teurasprosenttiin eikä ruhon lihakkuuteen, mutta sonnit rasvoittuivat enemmän pihatossa (EUROP-rasvaisuusluokka 3,3) kuin laitumella $(2,9)(\mathrm{P}<0,05)$. Laidunsonnien liha oli väriltään tummempaa kuin pihattosonnien $(\mathrm{P}<0,05)$. Pihattosonnien liha taas oli punaisempaa ja keltaisempaa kuin laidunsonnien $(\mathrm{P}<0,05)$. Laidunsonnien lihassa 18:1 $n-7$ (vakseenihappo), 18:2 n-6 (linolihappo), cis-9, trans-11-CLA ja 18:3 n-3 ( $\alpha$-linoleenihappo) rasvahappojen osuus ulkofileen rasvahapoista oli suurempi kuin pihattosonneilla. Pihattosonnien lihassa puolestaan 16:0 (palmitiinihappo) ja 14:1 n-5 (myristoleiinihappo) rasvahappojen osuus ulkofileen rasvahapoista oli suurempi kuin laidunsonneilla. Laiduntamisella ei tässä kokeessa ollut vaikutusta tyydyttyneiden tai tyydyttymättömien rasvahappojen osuuteen ulkofileessä. Laidunsonnien ulkofileissä oli enemmän monityydyttymättömiä rasvahappoja, mutta ero ei ollut tilastollisesti merkitsevä. Kasvatustavalla ei ollut vaikutusta rasvan $n-6 / n-3$ rasvahappojen suhteeseen.

Asiasanat: naudanlihantuotanto, tuotantoympäristö, laiduntaminen, sonnit, ruhon laatu, lihan laatu, rasvahappokoostumus, konjugoitu linolihappo, CLA 


\section{Johdanto}

Lihantuotantoon kasvatettavien sonnien laiduntaminen on Suomessa harvinaista joitakin yksittäisiä poikkeuksia lukuun ottamatta. Sonneja on perinteisesti pidetty huonoina ja rauhattomina laiduntajina, minkä vuoksi niiden kasvattamista laitumella ei ole pidetty järkevänä (Nisula ja Hakkola 1979). Lisäksi sonnien käsittely laitumella voi olla vaarallista. Sonnien laiduntamista ja niittoruokintaa on verrattu 1973-1974 Pohjois-Pohjanmaan tutkimusasemalla Ruukissa ilman väkirehulisää (Nisula ja Hakkola 1979, Hakkola ja Joki-Tokola 1987). Päiväkasvut jäivät tuolloin laitumella $140 \mathrm{~g} / \mathrm{pv}$ heikommaksi kuin navetassa niittoruokinnalla olleilla eläimillä. Tutkimuksessa todettiin, että puolivuotiaat ja sitä vanhemmat sonnit ovat rauhattomia laiduneläimiä, jotka sotkevat laidunta, minkä vuoksi laitumen hyväksikäyttö jää alhaiseksi. Niittoruokinnalla saatiin keskimäärin 1000 ry/ha suurempi sato kuin laiduntamalla (Hakkola ja Joki-Tokola 1987). Ulkomailla lihanautojen laiduntaminen on suhteellisen yleistä, mutta tulokset ovat heikosti hyödynnettävissä Suomen olosuhteisiin, sillä tutkimukset on toteutettu pääasiassa kastroiduilla naudoilla (esim. Comerford ym. 2001).

Viime vuosina on tutkittu runsaasti ruokinnan vaikutusta maidon ja naudanlihan rasvan koostumukseen. Laiduntamisen on havaittu muuttavan naudanlihan rasvahappokoostumusta terveellisemmäksi. Laiduntaminen on tutkimuksissa muun muassa pienentänyt $n-6$ rasvahappojen suhdetta $n-3$ rasvahappoihin (French ym. 2000, Nuernberg ym. 2002), lisännyt terveysvaikutteisen konjugoidun linolihapon eli CLA:n pitoisuutta naudanlihassa (Garcia ym. 2005) ja pienentänyt tyydyttyneiden rasvahappojen osuutta lihaksensisäisestä rasvasta (French ym. 2000). Konjugoidulla linolihapolla on havaittu olevan syöpää ehkäisevä vaikutus (Ip ym. 1999) sekä positiivisia vaikutuksia muun muassa kakkostyypin diabetekseen, rasvametaboliaan, luuston terveyteen ja vastustuskykyyn (Pariza ym. 2001, Scollan ym. 2006). Tämän tutkimuksen tavoitteena oli selvittää, miten laidunkasvatus vaikuttaa hereford-rotuisten sonnien kasvuun, ruhon laatuun sekä naudanlihan rasvahappokoostumukseen pihattokasvatukseen verrattuna.

\section{Aineisto ja menetelmät}

Tutkimus toteutettiin Maa- ja elintarviketalouden tutkimuskeskuksella (MTT) Ruukissa kesäheinäkuussa 2005. Tutkimus oli osa EU:n Interreg III B -ohjelmasta rahoitettua Barents Agro Forum hanketta, ja se toteutettiin MTT:n ja Lihateollisuuden tutkimuskeskuksen yhteistyönä. Kokeessa oli 29 hereford-rotuista sonnia, jotka olivat kokeen alkaessa keskimäärin 14 kuukauden ikäisiä. Eläimet siirrettiin MTT:n Tohmajärven emolehmänavetalta Ruukkiin syksyllä 2004. Sonnivasikat olivat laiduntaneet Tohmajärvellä kesän emojensa kanssa ja olivat tottuneet varomaan sähköaitaa. Kaikki eläimet viettivät koetta edeltävän talven eristämättömässä pihatossa viiden eläimen karsinoissa, ja söivät seosrehua. Seosrehun kuiva-aineesta 60 prosenttia oli nurmisäilörehua ja 40 prosenttia väkirehua (ohrarehua ja ohraa).

Laidunryhmässä oli 15 sonnia ja sonnit laidunsivat kolmessa viiden sonnin ryhmässä. Vertailuryhmä (14 sonnia) kasvatettiin eristämättömässä pihatossa ryhmäkarsinoissa. Pihattoryhmät koostuivat yhdestä neljän ja kahdesta viiden sonnin ryhmästä. Koe kesti 62 vuorokautta (1.6.-1.8.2005). Sonnit viettivät ennen laitumelle laskua kaksi tuntia noin 20 × 20 m kokoisessa metalliaitaelementeistä tehdyssä totutteluaitauksessa. Eläimet päästettiin laitumelle, kun ne olivat rauhoittuneet. Laitumet oli jaettu lohkoihin, joita oli jokaisella ryhmällä käytössään neljä kesäkuun alusta heinäkuun puoliväliin. Heinäkuun puolivälin jälkeen otettiin käyttöön kaksi lisälohkoa, joilta oli korjattu ensimmäinen säilörehusato. Alkukesästä käytössä olleiden laidunlohkojen koko oli keskimäärin noin 0,34 ha ja lisälohkot olivat noin 0,26 ha. Laidunalaa oli eläintä kohti alkukesästä yhteensä noin 0,27 ha ja loppukesästä noin 0,37 ha. Laidun oli timoteinurmea, jota lannoitettiin ja puhdistusniitettiin tarpeen mukaan. Laidunlohkoja syötettiin 3-7 päivän ajan. Pihattosonnit saivat vapaasti nurmisäilörehua. Sekä laitumella että pihatossa annettiin päivässä väkirehua (ohra) $5 \mathrm{~kg} / \mathrm{sonni} \mathrm{ja} \mathrm{kivennäistä} 150 \mathrm{~g} / \mathrm{sonni}$.

Sonnit punnittiin kokeen alussa ja lopussa kahtena peräkkäisenä päivänä. Eläimet teurastettiin 2.8.2005 normaalin teurastuskäytännön mukaisesti Atrian teurastamossa Kuopiossa. Teuraspaino määritettiin sen jälkeen, kun ruhosta oli poistettu pää, vuota, jalat, häntä, sisäelimet sekä sisälmysrasva. Ruhot luokiteltiin EUROP -luokituksen mukaisesti, jossa E kuvaa erittäin lihaksikasta ja P erittäin heikkoa ruhoa. Ruhojen rasvaisuus luokiteltiin asteikolla 1-5, jossa 1 kuvaa erittäin vähärasvaista ja 5 erittäin rasvaista ruhoa. Sonnien päiväkasvu laskettiin loppupainon ja kokeen alun painon erotuksena jaettuna kasvatuspäivillä. Nettokasvu laskettiin teuraspainon ja kokeen alun ruhopainon erotuksena jaettuna kasvatuspäivillä. Ruhopaino kokeen alussa laskettiin kaavalla: elopaino x 0,53. 
Rehunkulutus mitattiin pihatossa päivittäin punnitsemalla rehuannokset ja rehujätteet. Laitumella mitattiin vain väkirehun syönti. Ennen syötön alkamista kullekin laidunlohkolle tehtiin kasvuston botaaninen määritys, jonka yhteydessä laitumesta kerättiin näytteet rasvahappo- ja rehuanalyysiä varten. Rasvahapponäytteet jäähdytettiin välittömästi, kun näyte oli leikattu ja pakastettiin mahdollisimman pian. Ennen ja jälkeen laidunnuksen kultakin laidunlohkolta määritettiin kasvuston määrä mittaamalla laidunruohon pituus mittatikulla. Syötössä olleesta säilörehusta otettiin kaksi kertaa kuukaudessa rehunäyte. Näytteet yhdistettiin vastaamaan kunkin ruokintajakson (4 viikkoa) aikana syötettyä säilörehua. Ohrasta ja kivennäisestä näytteet otettiin jokaisesta erästä (siilo/säkki). Ohran ja kivennäisen analyysinäytteenä käytettiin kahden ruokintajakson aikana kerätyistä osanäytteistä yhdistettyjä kokonaisnäytteitä.

Rehunäytteistä määritettiin kuiva-aine, tuhka, raakavalkuainen ja neutraalidetergenttikuitu MTT:1lä käytössä olevin standardimenetelmin (ks. esim. Huuskonen ym. 2007). Rehujen rasvapitoisuus määritettiin AOAC:n (1990) ja rasvahappokoostumus Metcalfen ja Schmitzin (1961) ja Haran ja Radinin (1978) mukaan. Laidunruohon sulavuus määritettiin Friedelin (1990) mukaan. Säilörehun Darvo mitattiin Valio Oy:n laboratoriossa Seinäjoella NIR-menetelmällä (Nousiainen ym. 2004). Säilörehusta määritettiin käymislaatu ( $\mathrm{pH}$, kokonaistyppi, liukoinen typpi, ammoniumtyppi, vesiliukoiset hiilihydraatit, haihtuvat rasvahapot sekä maito- ja muurahaishappo) Valio Oy:ssä käytössä olevalla puristenestetitraukseen pohjautuvalla laatumäärityksellä (Moisio ja Heikonen 1989). Rehujen sisältämä muuntokelpoisen energian (ME) pitoisuus laskettiin rehutaulukoissa kuvatuilla menetelmillä (MTT 2006). Rehuyksikköarvot (ry) laskettiin jakamalla ME-arvo 11,7:1lä (MTT 2006). Ohutsuolesta imeytyvien aminohappojen (OIV) saanti ja rehujen OIV-arvot laskettiin Suomen olosuhteisiin muunnetun pohjoismaisen valkuaisarvojärjestelmän mukaisesti (MTT 2006).

Teurastusta seuraavana päivänä toisesta ruhonpuolikkaasta leikattiin lihan laatuanalyyseihin noin $2 \mathrm{~kg}$ ulkofileenäyte kolmen viimeisen lannenikaman alueelta. Ulkofileenäytteestä analysoitiin lihan väri (Minolta Chroma Meter CR-2000 mittari) Lihateollisuuden tutkimuskeskuksessa. Rasvahappokoostumus mitattiin MTT:n Kemian laboratoriossa Jokioisilla noin kuukauden pakkasvarastoinnin jälkeen. Menetelmänä oli pitkäketjuisten rasvahappojen määrittäminen GC-MS:lla (Metcalfe ja Schmitz 1961, Hara ja Radin 1978). Tulosten tilastolliseen käsittelyyn käytettiin SAS-ohjelmiston GLM-proseduuria. Koekäsittelyiden erot testattiin varianssianalyysillä.

Taulukko 1. Rehujen keskimääräinen kemiallinen koostumus, rehuarvo ja säilörehun säilönnällinen laatu.

\begin{tabular}{lccc}
\hline & Säilörehu & Laidunruoho & Ohra \\
\hline Kuiva-aine, g/kg & 230 & 197 & 907 \\
Kuiva-aineessa, g/kg ka & & & \\
$\quad$ Raakavalkuainen & 171 & 200 & 139 \\
Neutraalidetergenttikuitu & 508 & 479 & 288 \\
OIV $^{1)}$ & 88 & 92 & 106 \\
$\quad$ Raakarasva & 43 & 39 & 34 \\
D-arvo & 71 & 73 & - \\
Energia-arvo, ry/kg ka & 0,97 & 1,00 & 1,11 \\
Säilörehun säilönnällinen laatu & & & \\
pH & 3,78 & & \\
Haihtuvat rasvahapot, g/kg ka & 20 & & \\
Maito- ja muurahaishappo, g/kg ka & 61 & & \\
Kokonaistypestä, g/kg N & & & \\
$\quad$ NH ${ }_{4} \mathrm{~N}$ & 50 & & \\
$\quad$ Liukoinen N & 500 & & \\
\hline
\end{tabular}

\footnotetext{
1) Ohutsuolesta imeytyvä valkuainen (MTT 2006).

2) Sulavan orgaanisen aineen pitoisuus rehun kuiva-aineessa prosentteina.
} 


\section{Tulokset ja tulosten tarkastelu \\ Kasvusto ja rehut}

Laidunlohkojen kuiva-ainesato oli keskimäärin $2200 \mathrm{~kg} / \mathrm{ha}(700-4200 \mathrm{~kg} / \mathrm{ha})$, ja rikkakasveja oli loppukesästä jopa yli 70 prosenttia ruohon kuiva-aineesta. Rikkakasvit olivat pääasiassa juolavehnää. Laidunruohon pituus oli ennen laiduntamista keskimäärin $30 \mathrm{~cm}(15-51 \mathrm{~cm})$ ja laiduntamisen jälkeen $17 \mathrm{~cm}(8-27 \mathrm{~cm})$. Laidunrehun D-arvo oli keskimäärin 73 prosenttia ja säilörehun D-arvo 71 prosenttia. Kokeessa käytetty nurmisäilörehu oli säilönnälliseltä laadultaan hyvää (Taulukko 1). Laidunruohossa oli suurempi raakavalkuais- ja OIV-pitoisuus, mutta pienempi NDF-pitoisuus kuin nurmisäilörehussa (Taulukko 1).

Kokeessa käytettyjen rehujen rasvahappokoostumukset on esitetty taulukossa 2. Säilörehussa oli selkeästi enemmän linolihappoa (C18:2 n-6), mutta vähemmän alfa-linoleenihappoa (C18:3n-3) kuin laidunruohossa. Suurimmat öljyhappo- (C18:1 n-9) ja linolihappopitoisuudet olivat ohranäytteissä. Ohran rasvahapoista suurin osa oli linolihappoa, jota oli 51,3 prosenttia kokonaisrasvahapoista.

Taulukko 2. Kokeessa käytettyjen rehujen rasvahappokoostumukset.

\begin{tabular}{lccc}
\hline $\begin{array}{l}\text { Rasvahappokoostumus, } \\
\text { \% rasvahapoista }\end{array}$ & Laidun & Säilörehu & Ohra \\
\hline 14:0 (myristiinihappo) & 0,3 & 0,4 & 0,1 \\
16:0 (palmitiinihappo) & 14,3 & 16,6 & 18,4 \\
16:1 $n$-7 (palmitoleiinihappo) & 2,2 & 2,1 & 0,1 \\
18:0 (steariinihappo) & 2,1 & 1,5 & 1,0 \\
18:1 $n$-7 (vakseenihappo) & 0,4 & 0,8 & 1,0 \\
18:1 $n$-9 (öljyhappo) & 2,0 & 4,4 & 17,4 \\
18:2 $n$-6 (linolihappo) & 15,1 & 21,8 & 51,3 \\
18:3 $n$-3 (alfa-linoleenihappo) & 59,4 & 49,3 & 9,1 \\
20:0 (arakidiinihappo) & 1,7 & 1,0 & 0,2 \\
22:0 (beheenihappo) & 1,8 & 1,5 & 0,0 \\
22:2 (metyyli dokosadienoaatti) & 0,0 & 0,0 & 0,0 \\
24:0 (lignoseriinihappo) & 0,5 & 0,6 & 0,0 \\
tyydyttyneet & 20,8 & 21,6 & 19,7 \\
kertatyydyttymättömät & 4,7 & 7,3 & 19,8 \\
monityydyttymättömät & 74,5 & 71,1 & 60,4 \\
\hline
\end{tabular}

\section{Eläinten kasvu ja ruhon laatu}

Eläinten välisestä suuresta hajonnasta johtuen kasvatustapojen välillä ei ollut tilastollisesti merkitseviä eroja päivä- tai nettokasvussa. Laidunsonnit näyttivät kuitenkin kasvavan hieman hitaammin kuin pihattosonnit (Taulukko 3). Tulokset vastaavat Janssonin ym. (2006) kokeessa ay-rotuisilla sonneilla saatuja kasvutuloksia, sillä myöskään tuossa tutkimuksessa laitumella ja pihatossa loppukasvatettujen sonnien kasvutuloksissa ei ollut tilastollisesti merkitsevää eroa.

Kasvatustapa ei vaikuttanut sonnien teurasprosenttiin eikä ruhojen lihakkuuteen (Taulukko 3). Pihattosonnit olivat kuitenkin keskimäärin rasvaisempia kuin laidunsonnit $(\mathrm{P}<0,05)$. Mahdollinen syy pihattosonnien voimakkaampaan rasvoittumiseen on laidunsonnien suurempi liikkumisaktiivisuus (Tuomisto ym. 2008). Mossbergin ym. (1992, 1993) mukaan lisääntyneen liikunnan seurauksena eläimet kuluttavat enemmän energiaa ja niihin kerääntyy enemmän lihaskudosta ja vähemmän rasvakudosta. 
Taulukko 3. Sonnien kasvu- ja teurastulokset.

\begin{tabular}{|c|c|c|c|c|}
\hline & Laidun & Pihatto & SEM $^{1)}$ & Tilastollinen merkitsevyys $^{2)}$ \\
\hline Eläinten lukumäärä & 15 & 14 & & \\
\hline Elopaino kokeen alussa, $\mathrm{kg}$ & 528 & 527 & 10,7 & \\
\hline Elopaino kokeen lopussa, kg & 614 & 622 & 13,4 & \\
\hline \multicolumn{5}{|l|}{ Kasvu $\mathrm{g} \mathrm{pv}^{-1}$} \\
\hline Päiväkasvu kokeen aikana & 1453 & 1604 & 93,5 & \\
\hline Nettokasvu kokeen aikana & 897 & 968 & 65,6 & \\
\hline \multicolumn{5}{|l|}{ Teurastulokset } \\
\hline Teuraspaino, kg & 335 & 339 & 7,9 & \\
\hline Teurasprosentti & 54,7 & 54,5 & 0,36 & \\
\hline Lihakkuus ${ }^{3)}$ & 6,3 & 6,7 & 0,22 & \\
\hline Rasvaisuus $^{4)}$ & 2,9 & 3,3 & 0,11 & $*$ \\
\hline
\end{tabular}

1) Keskiarvon keskivirhe.

2) $* * * \mathrm{P}<0,001, * * \mathrm{P}<0,01, * \mathrm{P}<0,05$, o $\mathrm{P}<0,1$.

${ }^{3)}$ EUROP-laatuluokitus, jossa $4=\mathrm{O}-, 5=\mathrm{O}, 6=\mathrm{O}+$ ja $7=\mathrm{R}-(\mathrm{O}=$ kohtalainen lihakkuus ja $\mathrm{R}=$ hyvä lihakkuus $)$.

${ }^{4)}$ EUROP-laatuluokitus, jossa $2=$ ohutrasvainen, $3=$ keskirasvainen ja $4=$ rasvainen.

\section{Ulkofileiden väri ja rasvahappokoostumus}

Tutkittujen ulkofileiden väri (vaaleus, punaisuus ja keltaisuus) olivat normaaleja (Taulukko 4). Laidunsonnien liha oli väriltään tummempaa kuin pihattosonnien $(\mathrm{P}<0,05)$. Pihattosonnien liha taas oli punaisempaa ja keltaisempaa kuin laidunsonnien $(\mathrm{P}<0,05)$.

Taulukko 4. Ulkofileen väri kokeessa.

\begin{tabular}{lcccc}
\hline & Laidun & Pihatto & SEM $^{1)}$ & Tilastollinen merkitsevyys $^{2)}$ \\
\hline Vaaleus, L-arvo & 39,2 & 41,0 & 0,40 & $*$ \\
Punaisuus, a-arvo & 26,6 & 27,8 & 0,27 & $*$ \\
Keltaisuus, b-arvo & 9,6 & 10,4 & 0,16 & $*$ \\
\hline
\end{tabular}

${ }^{1)}$ Keskiarvon keskivirhe.

2) *** $\mathrm{P}<0,001, * * \mathrm{P}<0,01, * \mathrm{P}<0,05$, o $\mathrm{P}<0,1$.

Laiduntaminen lisäsi 18:1 n-7 (vakseenihappo), 18:2 n-6 (linolihappo), cis-9, trans-11-CLA:n ja 18:3 $n$-3 ( $\alpha$-linoleenihappo) rasvahappojen osuutta ulkofileen rasvahapoista (Taulukko 5). Pihattosonnien lihassa taas oli suurempi osuus 16:0 (palmitiinihappo) ja 14:1 $n-5$ (myristoleiinihappo) rasvahappoja verrattuna laidunsonneihin. Laiduntamisella ei tässä kokeessa ollut vaikutusta tyydyttyneiden tai tyydyttymättömien rasvahappojen pitoisuuksiin naudanlihassa. Laidunsonnien ulkofileissä oli enemmän monityydyttymättömiä rasvahappoja, mutta ero ei ollut tilastollisesti merkitsevä. Kasvatustavalla ei ollut vaikutusta rasvan $n-6 / n-3$ rasvahappojen suhteeseen.

Rasvahappojen vaikutusta ihmisten terveyteen on tutkittu runsaasti viime vuosina. Suomalaisten ravitsemussuositusten mukaan kuluttajien pitäisi vähentää tyydyttyneiden ja transrasvahappojen (ns. kova rasva) saantia sekä lisätä kerta- ja monityydyttymättömien rasvahappojen osuutta rasvan saannista (Valtion ravitsemusneuvottelukunta 2005). Omega-3 (n-3) rasvahapoista erityisesti eikosapentaeenihapon (20:5 n-3) ja dokosaheksaeenihapon (22:6n-3) on havaittu ehkäisevän sydän- ja verisuonitauteja (Simopoulos 1999). Myös $\alpha$-linoleenihapolla (18:3 n-3) saattaa olla terveyttä edistäviä vaikutuksia (Simopoulos 1999). Naudan lihaksensisäisen rasvan rasvahapoista on noin 47 prosenttia tyydyttyneitä, 42 prosenttia kertatyydyttymättömiä ja 4 prosenttia monityydyttymättömiä (Scollan 2003). Pötsibakteerit hydrogenoivat rehun tyydyttymättömiä rasvahappoja, minkä vuoksi märehtijän varastorasvoissa on runsaasti tyydyttyneitä rasvahappoja (McDonald ym. 2002). Naudanlihassa on kuitenkin edullisempi $n-6$ ja $n-3$ rasvahappojen suhde kuin esimerkiksi sianlihassa (Wood ja Enser 1997), minkä lisäksi märehtijöistä peräisin olevat maito- ja lihatuotteet ovat konjugoidun linolihapon (CLA) pääasiallinen lähde ihmisillä (Wood ja Enser 1997).

Konjugoidulla linolihapolla on havaittu useita terveysvaikutuksia: muun muassa syöpää ehkäisevä vaikutus (Ip ym. 1999). Linolihappoa sisältävien rehujen syöttäminen vaikuttaa lisäävän tehokkaimmin naudanlihan CLA-pitoisuutta. Karkearehujen, kuten esimerkiksi ruohon tai palkokasveista tehdyn heinän syöttäminen näyttäisivät muodostavan pötsiin sellaiset olosuhteet ja mikroflooran, jotka edistävät CLA:n muodostumista ja kertymistä kudoksiin (Mir ym. 2004). 
Taulukko 5. Ulkofileen rasvahappokoostumukset.

\begin{tabular}{|c|c|c|c|c|}
\hline $\begin{array}{l}\text { Rasvahappokoostumus, \% rasvaha- } \\
\text { poista }\end{array}$ & Laidun & Pihatto & $\mathrm{SEM}^{1)}$ & Tilastollinen merkitsevyys $^{2}$ ) \\
\hline 14:0 (myristiinihappo) & 1,95 & 2,22 & 0,112 & \\
\hline 14:1 n-5 (myristoleiinihappo) & 0,01 & 0,13 & 0,027 & $*$ \\
\hline 15:0 (pentadekanoiinihappo) & 0,00 & 0,00 & & \\
\hline 16:0 (palmitiinihappo) & 20,11 & 21,40 & 0,283 & $*$ \\
\hline $16: 1 n-7$ (palmitoleiinihappo) & 2,53 & 2,84 & 0,123 & \\
\hline 17:0 (heptadekaanihappo) & 1,02 & 0,94 & 0,037 & \\
\hline 17:1 (10-heptadekeenihappo) & 0,66 & 0,69 & 0,017 & \\
\hline 18:0 (steariinihappo) & 18,74 & 17,93 & 0,409 & \\
\hline 18:1 n-7 (vakseenihappo) & 1,80 & 1,57 & 0,037 & $* * *$ \\
\hline 18:1 n-9 (öljyhappo) & 34,06 & 34,61 & 0,333 & \\
\hline 18:2 n-6 (linolihappo) & 8,44 & 6,88 & 0,367 & $*$ \\
\hline 18:2 cis-9, trans-11-CLA & 0,42 & 0,28 & 0,026 & $* *$ \\
\hline 18:3 n-3 (alfa-linoleenihappo) & 2,00 & 1,53 & 0,079 & $* *$ \\
\hline 20:0 (arakidiinihappo) & 0,11 & 0,11 & 0,009 & \\
\hline 20:1 n-9 (eikoseenihappo) & 0,06 & 0,05 & 0,010 & \\
\hline 20:2 n-6 (eikosadieenihappo) & 0,25 & 0,25 & 0,014 & \\
\hline 20:3 (dihomolinoleenihappo) & 0,39 & 0,38 & 0,025 & \\
\hline 20:4 n-6 (arakidonihappo) & 2,69 & 2,78 & 0,205 & \\
\hline 20:5 n-3 (eikosapentaeenihappo) & 0,75 & 0,59 & 0,060 & \\
\hline 22:5 n-3 (dokosapentaeenihappo) & 1,05 & 1,05 & 0,070 & \\
\hline tunnistamaton rasvahappo & 2,95 & 3,78 & 0,211 & $*$ \\
\hline tyydyttyneet rasvahapot & 41,94 & 42,59 & 0,684 & \\
\hline kertatyydyttymättömät rasvahapot & 39,13 & 39,89 & 0,393 & \\
\hline monityydyttymättömät rasvahapot & 15,98 & 13,74 & 0,738 & \\
\hline
\end{tabular}

1) Keskiarvon keskivirhe.

2) *** $\mathrm{P}<0,001, * * \mathrm{P}<0,01, * \mathrm{P}<0,05, \mathrm{o} \mathrm{P}<0,1$.

Tässä kokeessa sonnien cis-9, trans-11 CLA-pitoisuus oli keskimäärin 0,35 prosenttia kokonaisrasvahapoista. Ulkomaisissa tutkimuksissa cis-9, trans-11 CLA-pitoisuudet olivat hereford-härillä 0,23 0,41 (Realini ym. 2004), liharoturisteytyshärillä 0,37-1,08 (French ym. 2000), simmental-sonneilla $0,56-0,60$, holstein-härillä $0,52-0,55$ (Nuernberg ym. 2002) sekä angus-hereford-risteytyshärillä $0,25-$ 0,31 (Griswoldin ym. 2003) prosenttia kokonaisrasvahapoista. Laiduntaminen on monissa tutkimuksissa lisännyt CLA:n pitoisuutta naudanlihassa (esim. Realini ym. 2004, Garcia ym. 2005), mutta Nuernbergin ym. (2002) tutkimuksessa laiduntaminen ei muuttanut simmental-sonnien ja holsteinhärkien lihan CLA-pitoisuutta, kun sitä verrattiin väkirehuruokintaan. Tässä raportoidussa kokeessa laiduntaminen lisäsi hereford-sonnien cis-9, trans-11 CLA:n pitoisuutta kokonaisrasvahapoista verrattuna pihattokasvatukseen. Ulkomaisissa tutkimuksissa laiduntamista on usein verrattu väkirehuvaltaiseen ruokintaan. Tässä tutkimuksessa sekä laidun- että pihattokasvatuksessa eläimet saivat yhtä paljon väkirehua.

\section{Yhteenveto ja johtopäätökset}

Kasvatustavalla ei ollut tilastollisesti merkitsevää vaikutusta sonnien kasvutuloksiin. Sonnit kuitenkin rasvoittuivat enemmän pihatossa kuin laitumella. Mahdollinen syy tähän on laidunsonnien suurempi liikkumisaktiivisuus. Ulkofileen rasvan cis-9, trans-11 CLA- ja $\alpha$-linoleenihappopitoisuudet olivat suurempia laidunsonneilla kuin pihattosonneilla. Kasvatustavalla ei ollut vaikutusta ulkofileen tyydyttymättömien ja tyydyttyneiden rasvahappojen kokonaispitoisuuksiin.

\section{Kirjallisuus}

AOAC 1990. Official Methods of Analysis. Arlington, VA: Association of Official Analytical Chemists. 1298 s. Comerford, J.W., Harpster, H.W. \& Baumer, V.H. 2001. The effects of grazing, liquid supplements, and implants on feedlot performance and carcass traits of Holstein steers. J. Anim. Sci. 79: 325-332.

French, P., Stanton, C., Lawless, F., O’Riordan, E.G., Monahan, F.J., Caffrey, P.J. \& Moloney, A.P. 2000. Fatty acid composition, including conjugated linoleic acid, of intramuscular fat from steers offered grazed grass, grass silage, or concentrate-based diets. J. Anim. Sci. 78: 2849-2855. 
Friedel, K. 1990. Die Schätzung des energetischen Futterwertes von Grobfutter mit Hilfe einer Cellulasemethode. Wissenschaftliche Zeitschrift Universitet Rostock, N-Reihe 39: 78-86.

Garcia, P.T., Pensel, N.A., Latimori, N.J., Kloster, A.M., Amigone, M.A. \& Casal, J.J. 2005. Intramuscular lipids in steers under different grass and grain regimen. Fleisch wirtschaft international 1: 27-31.

Griswold, K.E., Apgar, G.A., Robinson, R.A., Jacobson, B.N., Johnson, D. \& Woody, H.D. 2003. Effectiveness of short-term feeding strategies for altering conjugated linoleic acid content of beef. J. Anim. Sci. 81: 18621871.

Hakkola, H. \& Joki-Tokola, E. 1987. Eri tavoin korjatut nurmirehut lihanautojen ruokinnassa. Teoksessa: Pulli, S., Näsi, M., Vainio-Mattila, I. Hartikainen, H. \& Haapa, M. (toim.). Maataloustieteen päivät. Suomen Maataloustieteellisen Seuran tiedote no 9. Helsinki: Suomen Maataloustieteellinen Seura. s. 56-64.

Hara, A. \& Radin, N. S. 1978. Lipid extraction of tissues with a low-toxicity solvent. Analytic. Biochem. 50: 420-426.

Huuskonen, A., Khalili, H. \& Joki-Tokola, E. 2007. Effects of three different concentrate proportions and rapeseed meal supplement to grass silage on animal performance of dairy-breed bulls with TMR feeding. Livest. Sci. 110: 154-165.

Ip, C., Banni, S., Angioni, E., Carta, G., McGinley, J., Thompson, H.J., Barbabano, D. \& Bauman, D. 1999. Conjugated linoleic acid-enriched butter alters mammary gland morphogenesis and reduces cancer risk in rats. J. Nutr. 129: 2135-2142.

Jansson, S., Honkavaara, M. \& Huuskonen, A. 2006. Maitorotuisten sonnien laiduntaminen. a) Vaikutus tuotantoon ja lihan laatuun. Julkaisussa: Maataloustieteen Päivät 2006 (verkkojulkaisu). Suomen Maataloustieteellisen Seuran julkaisuja no 21. Toim. Anneli Hopponen. 7 s. Saatavilla internetistä: http//www.smts.fi.

McDonald, P., Edwards, R.A., Greenhalgh, J.F.D. \& Morgan, C.A. 2002. Animal nutrition. 6. painos. Harlow: Prentice Hall. 693 s. ISBN 0582419069.

Metcalfe, L. D. \& Schmitz, A. A. 1961. The rapid preparation of fatty acid esters for gaschromatographic analysis. Analytic. Chem. 33: 363-364.

Mir, P.S., McAllister, T.A., Scott, S., Aalhus, J., Baron, V., McCartney, D., Charmley, E., Goonewardene, L., Basarab, J., Okine, E., Weselake, R.J. \& Mir, Z. 2004. Conjugated linoleic acid-enriched beef production. Am. J. Clinic. Nutr. 79 (Suppl.): 1207S-1211S.

Moisio, T. \& Heikonen, M. 1989. A titration method for silage assessment. Anim. Feed Sci. Technol. 22: 341353 .

Mossberg, I., Lindell, L., Johnsson, S., Törnquist, M. \& Engstrand, U. 1992. Two housing systems for intensively reared bulls slaughtered in two weight ranges. Acta Agric. Scand., Sect. A, Anim. Sci. 42: 167-176.

Mossberg, I., Lindell, L., Johnsson, S. \& Tornquist, M. 1993. Insulated and uninsulated housing systems for growing bulls fed grass silage ad libitum. Acta Agric. Scand., Sect. A, Anim. Sci- 43: 107-115.

MTT 2006. Rehutaulukot ja ruokintasuositukset [verkkojulkaisu]. Jokioinen: Maa- ja elintarviketalouden tutkimuskeskus. Saatavissa internetistä: http://www.agronet.fi/rehutaulukot/.

Nisula, H. \& Hakkola, H. 1979. Lihanautojen määrän vaikutus laitumen satoon. Kehittyvä maatalous 42: 12-22. Nousiainen, J., Ahvenjärvi, S., Rinne, M., Hellämäki, M. \& Huhtanen, P. 2004. Prediction of indigestible cell wall fraction of grass silage by near infrared reflectance spectroscopy. Anim. Feed Sci. Technol. 115: 295311.

Nuernberg, K., Nuernberg, G. Ender, K., Lorenz, S., Winkler, K., Rickert, R. \& Steinhart, H. 2002. N-3 fatty acids and conjugated linoleic acids of longissimus muscle in beef cattle. Europ. J. Lipid Sci. Technol. 104: 463-471.

Pariza, M.W., Park, Y. \& Cook, M.E. 2001. The biological active isomers of conjugated linoleic acid. Progress in Lipid Research 40: 283-298.

Realini, C.E., Duckett, S.K., Brito, G.W., Dalla Rizza, M. \& De Mattos, D. 2004. Effect of pasture vs. concentrate feeding with or without antioxidants on carcass characteristics, fatty acid composition, and quality of Uruguayan beef. Meat Sci. 66: 567-577.

Scollan, N. 2003. Strategies for optimising the fatty acid composition of beef. Iger Innovations 7: 41-45.

Scollan, N., Hocquette, J.F., Nuernberg, K., Dannenberger, D., Richardson, I. \& Moloney, A. 2006. Innovations in beef production systems that enhance the nutritional and health value of beef lipids and their relationship with meat quality. Meat Sci. 74: 17-33.

Simopoulos, A.P. 1999. Essential fatty acids in health and chronic disease. Am. J. Clinic. Nutr. 70: 560S-569S. Tuomisto, L., Martiskainen, P., Huuskonen, A. \& Ahola, L. 2008. Laidunnuksen vaikutus hereford-sonnien käyttäytymiseen. Julkaisussa: Maataloustieteen Päivät 2008 (verkkojulkaisu). Suomen Maataloustieteellisen Seuran julkaisuja no 23. Toim. Anneli Hopponen. 7 s. Saatavilla internetistä: http//www.smts.fi.

Valtion ravitsemusneuvottelukunta. 2005. Suomalaiset ravitsemussuositukset - ravinto ja liikunta tasapainoon. Edita Prima Oy: Helsinki 2005. http://www.mmm.fi/ravitsemusneuvottelukunta/FIN11112005.pdf.

Wood, J.D. \& Enser, M. 1997. Factors influencing fatty acids in meat and the role of antioxidants in improving meat quality. Br. J. Nutr. 78 (Suppl.): S49-S60. 